\title{
Schwartz's Value Types on Romantic Relationships: Exploratory Study on Balinese Society
}

\author{
Dewi Arum Widhiyanti M. P. ${ }^{1}$, Kwartarini Wahyu Yuniarti ${ }^{2}$, Wenty Marina Minza ${ }^{3}$, Bagus \\ Riyono 4 \\ \{dewiarumbk@gmail.com¹, kwartarini_psy@ugm.ac.id²,wminza@ugm.ac.id ${ }^{3}$, bagus@ugm.ac.id ${ }^{4}$ \}
}

Universitas Pendidikan Ganesha, Indonesia ${ }^{1}$

Universitas Gadjah Mada, Indonesia ${ }^{1,2,3,4}$

\begin{abstract}
The ecological perspective emphasizes the social and cultural context that encourages or inhibits close relationships and gives meaning. This means that the dynamics of romantic relations are inseparable from the values, norms and expectations that exist in a society's culture. The purpose of this study is to identify values that are considered important in romantic relationships by young generations of Balinese, especially in terms of the types of values proposed by Schwartz. Responses from Balinese adolescents $(n=320)$ obtained through questionnaires with open-ended questions were processed using thematic analysis. The results of this study indicate that the value of tradition dominates the consideration of Balinese adolescents in romantic relationships. The Balinese traditional values have characteristics that reflect other types of values, such as security, conformity, benevolence, and universalism values. Some Balinese philosophies and Hinduism emerge as examples of reference values that are used as a guide in interacting with the opposite sex, involvement in romantic relationships, and the selection of romantic partners. On the other side a number of adolescents suggest that they do not know about such values and do not consider them when establishing a romantic relationship.
\end{abstract}

Key words: Balinese, Romantic Relationship, Schwartz Theory, Values

\section{Introduction}

Romantic relationships are an important and normal part of adolescent development. Romantic relationships are defined as mutually recognized voluntary interactions, which have different intensities, generally characterized by expressions of affection and the possibilities of current or anticipated sexual behavior, when compared to other peer relationships [1][2].

Romantic relationships are a fundamental social psychological phenomenon. While individual feelings about romantic activities stem from their personal values, they also reflect ideological beliefs that are widely adopted by society and culture [3], including the structural, cultural, and closest contexts in which we live. These contextual ideological beliefs guide thoughts and actions, shape emotional experiences, and influence romantic expectations [3], and help identify appropriate objects of these feelings and behaviors [3][4] and provide a lens for individuals to interpret and react to events related to romantic experiences [5]. Romantic experiences are formed from cultural expectations or can be called social norms, which are cognitive maps that provide a set of expectations that guide individual behavior in social interactions [6]. 
Because romantic relationship understanding and experience tend to be products of existing cultural meaning systems [5], they reflect socially constructed representations of reality. In this way, our life arrangements, both micro and macro, become the background for our romantic relationships. The ecological perspective emphasizes the social and cultural context that encourages or inhibits close relationships and gives meaning. Values, norms, and expectations in romantic interactions form the background in which the relationship develops [7], Collectively over time, groups of individuals develop dispositions to act in certain ways in specific situations that align with these scripts during romantic encounters. Scripts are shaped by culturally based social norms, which are collective expectations, shared values, or cultural "rules" about how individuals should behave in a given situation and which are collectively reinforced through social sanctions, which are negative or positive reactions by others in reaction to conformity to these norms [6]. Norms are ideals and guide - but may not always describe - typical behavior. These scripts and norms can vary by the social location (gender, race, religiosity, sexual orientation, education, etc.) of various individuals and the intersections of these factors [8].

Balinese adolescents nowadays are experiencing romantic relationships in a community system that is known to be attached to traditional and religious values. On the other hand, interactions that are form in the context of romantic relations lead to a growing number of problematic behaviors that are not accepted by Balinese society, such as premarital sexual behavior and cohabiting. This condition raises questions about what values are considered by the Balinese people related to romantic relationships. By knowing about the values that are considered important, we can get a picture of the foundation, principles, or guidance that individuals have in behaving or taking actions when engaging in romantic relationships. Problematic behavior in romantic relationships can in turn be understood from what values are considered important and not important by individuals.

From the very beginning, psychological models of values have also recognized that societal values are a source of and influence on individual values [9]. Schwartz defined values as trans-situational goals, varying in importance, that serve as guiding principles in the life of a person or group. What differentiates among values is their distinct motivational content, the directions toward which the value points one's perceptions, decisions, and actions [10]. The Schwartz theory of basic human values, introduced in the last decade of the twentieth century, is the dominant approach in contemporary values research [9].

The value theory proposed by Schwartz and Cieciuch [9] shows that there are four higher order values, namely Self-transcendence, Conservation, Self-enhancement, and Openness to change. One dimension contrasts 'openness to change' and 'conservation' values. This dimension captures the conflict between values that emphasize independence of thought, action, and feelings and readiness for change (self-direction, stimulation) and values that emphasize order, self-restriction, preservation of the past, and resistance to change (security, conformity, tradition). The second dimension contrasts 'self-enhancement' and 'selftranscendence' values. This dimension captures the conflict between values that emphasize concern for the welfare and interests of others (universalism, benevolence) and values that emphasize pursuit of one's own interests and relative success and dominance over others (power, achievement). Hedonism shares elements of both openness to change and selfenhancement [11].

Next there are ten original values that are part of each of the higher order values, namely Benevolence, Universalism, Conformity, Tradition, Security, Power, Achievement, Hedonism, Stimulation, Self-direction. The ten values are defined based on the motivation behind each of these values. 
Table 1. Schwartz's Types of Values

\begin{tabular}{|l|}
\hline $\begin{array}{l}\text { Benevolence: Preservation and enhancement of the welfare of people with whom one is in } \\
\text { frequent personal contact }\end{array}$ \\
\hline $\begin{array}{l}\text { Universalism: Understanding, appreciation, tolerance, and protection for the welfare of all } \\
\text { people and of nature }\end{array}$ \\
\hline $\begin{array}{l}\text { Conformity: Restraint of actions, inclinations, and impulses that are likely to upset or } \\
\text { harm others and violate social expectations or norms }\end{array}$ \\
\hline $\begin{array}{l}\text { Tradition: Respect, commitment, and acceptance of the customs and ideas that traditional } \\
\text { culture or religion provides }\end{array}$ \\
\hline Security: Safety, harmony, and stability of society, relationships, and self \\
\hline Power: Social status and prestige, control, or dominance over people and resources \\
\hline $\begin{array}{l}\text { Achievement: Personal success through demonstrating competence according to social } \\
\text { standards }\end{array}$ \\
\hline Hedonism: Pleasure and sensuous gratification for oneself; \\
\hline Stimulation: Excitement, novelty, and challenge in life \\
\hline Self-direction: Independent thought and action, choosing, creating, and exploring \\
\hline
\end{tabular}

These values are likely to be universal because they are grounded in one or more of three universal requirements of human existence with which they help to cope. Values are the socially desirable concepts used to represent these goals mentally and the vocabulary is used to express them in social interactions [11][12].

Schwartz [13] proposes three bipolar dimensions of culture to compare cultures, namely autonomy versus embeddedness dimensions; egalitarian versus hierarchy; harmony versus mastery. In autonomy cultures, people should cultivate and express their own preferences, feelings, ideas, abilities, and uniqueness. In cultures with an emphasis on embeddedness, meaning in life comes largely through social relationships, through identifying with the group, participating in its shared way of life, and striving toward its shared goals. Important values in such cultures are social order, respect for tradition, security, obedience, and wisdom.

The polar solution labeled cultural egalitarianism seeks to induce people to recognize one another as moral equals who share basic interests as human beings. The alternative polar labeled cultural hierarchy relies on hierarchical systems of ascribed roles to insure responsible, productive behavior [13]. The cultural response labeled harmony emphasizes fitting into the world as it is, trying to understand and appreciate rather than to change, direct, or to exploit. Mastery in the other hand encourages active self-assertion in order to master, direct, and change the natural and social environment to attain groups or personal goals [13].

The purpose of this study is to identify the types of values possessed by Balinese adolescents and parents when related to romantic relations, by referring to the dimensions of values proposed by Schwartz. By knowing the values that are considered important in romantic relationships, it is hoped that this will become one of the foundations to obtain a dynamic picture of romantic relations in Balinese society from two generations through a more comprehensive ecological perspective. 


\section{Research Method}

This research is an explorative qualitative study. Data collection method used was survey through questionnaire with open-ended questions. Respondents in this study were Balinese adolescent boys and girls $(n=320)$, aged 14-19 years. Respondents answered the question, which was "what values do you consider important when establishing romantic relationships?". Data were analyzed through thematic analysis to group the types of values identified by respondents into the basic value categories of the theory proposed by Schwartz.

\section{Results and Discussions}

The results of data analysis gave rise to several value groups from the theory of value types proposed by Schwartz. The value groups responses appear to be related to one another given that Balinese society is generally attached to traditional values that are characterized by conformity values, security values, benevolence values, and universalism values.

Table 2. Groups of Responses

\begin{tabular}{|c|c|c|}
\hline Responses Group & Explanations & Types of Value \\
\hline \multicolumn{3}{|c|}{ 1. Religious beliefs: } \\
\hline Catur Asrama & $\begin{array}{l}\text { Four stages or levels of life, namely (1) } \\
\text { Brahmacari, the level of human life to seek } \\
\text { knowledge; (2) Grhasta, stages for fostering } \\
\text { households; (3) Wanaprasta, the stage where } \\
\text { humans begin to break away from worldly ties to } \\
\text { get closer to God; (4) Sannyasin / Bhiksuka, the } \\
\text { stage where the individual has freed from material } \\
\text { and mental ties with his family and himself, attained } \\
\text { purity, and is ready to become one with God } \\
\text { (Brahman) }\end{array}$ & $\begin{array}{l}\text { Tradition, } \\
\text { Conformity, } \\
\text { Security }\end{array}$ \\
\hline Tri Hita Karana & $\begin{array}{l}\text { Three components that cause happiness, which } \\
\text { include (1) Parahyangan, a harmonious relationship } \\
\text { between humans and God; (2) Pawongan, a } \\
\text { harmonious relationship with fellow human beings; } \\
\text { (3) Palemahan, harmonious relations with the } \\
\text { environment / nature. }\end{array}$ & $\begin{array}{l}\text { Tradition, } \\
\text { Universalism, } \\
\text { Benevolence }\end{array}$ \\
\hline Tat Twan Asi & Means "I am you and you are me" & $\begin{array}{l}\text { Tradition, } \\
\text { Benevolence }\end{array}$ \\
\hline $\begin{array}{l}\text { Prohibition of } \\
\text { premarital sex } \\
\text { and cohabitation }\end{array}$ & & $\begin{array}{l}\text { Tradition, } \\
\text { Conformity }\end{array}$ \\
\hline \multicolumn{3}{|c|}{ 2. Philosophy: } \\
\hline $\begin{array}{l}\text { Luh Luwih Luh } \\
\text { Luu }\end{array}$ & $\begin{array}{l}\text { Women are required to be able to maintain their } \\
\text { self-esteem so not to be considered bad by the } \\
\text { community. (Luh luwih = good / noble woman; Luh } \\
\text { luu: women who become "trash"). }\end{array}$ & $\begin{array}{l}\text { Tradition, } \\
\text { Conformity }\end{array}$ \\
\hline
\end{tabular}




\begin{tabular}{|l|l|l|}
\hline \multicolumn{3}{|c|}{ 3. Tradition/customs: } \\
\hline $\begin{array}{l}\text { Caste and } \\
\text { religious } \\
\text { considerations }\end{array}$ & Choose a partner from the same caste and religion. & $\begin{array}{l}\text { Tradition, } \\
\text { Security }\end{array}$ \\
\hline $\begin{array}{l}\text { Differences in } \\
\text { gender roles }\end{array}$ & $\begin{array}{l}\text { Differences in the roles and responsibilities of men } \\
\text { and women are determined by culture. }\end{array}$ & $\begin{array}{l}\text { Tradition, } \\
\text { Conformity }\end{array}$ \\
\hline $\begin{array}{l}\text { Prohibition of } \\
\text { Incest }\end{array}$ & $\begin{array}{l}\text { Should not be in a romantic relationship with } \\
\text { siblings. }\end{array}$ & Tradition \\
\hline \multicolumn{3}{|c|}{ 4. Attitude in relationships } \\
\hline $\begin{array}{l}\text { Politeness, shame, protecting family name, honesty, affection, respect, } \\
\text { faithful, understanding, caring, friendliness, responsibility, sincere, and } \\
\text { not being forceful to the partner. }\end{array}$ & $\begin{array}{l}\text { Benevolence, } \\
\text { Conformity, } \\
\text { Security }\end{array}$ \\
\hline \multicolumn{3}{|c|}{ 5. The role of parents } \\
\hline Romantic relationships must obtain the blessing of parents. & Conformity \\
\hline
\end{tabular}

For Balinese adolescents, attitudes and behaviors that are important to consider in romantic relationships are dominated by traditional values that characterize Balinese culture. Tradition values according to Schwartz related to the acceptance and commitment to habits and thoughts that exist in culture and religion. The Balinese in this case believe that romantic relationships are carried out based on values derived from religious teachings and philosophies that can be implemented when interacting with members of the opposite sex. Hinduism belief itself has in turn become a philosophy of Balinese life that is more implicative in their lives. Hindu teachings, basically have become part of Balinese culture and generally reflect the values that prioritize the good for the common welfare. Romantic relationship itself is a form of personal relationship between individuals but can be a representation of how values in society are understood and internalized by individuals in a particular culture.

Balinese culture has the characteristics of upholding customs and philosophy that leads to balance and harmony in life. The philosophy of Balinese society that has been widely recognized is Tri Hita Karana. This Tri Hita Karana philosophy, represents the basic values of Universalism, because this philosophy is a guideline for fostering harmony with God (Parahyangan), the environment (Palemahan), and fellow humans (Pawongan) [14]. Universalism values guide the Balinese to develop an attitude of understanding, respect, tolerance and maintaining environmental welfare. One part of this philosophy, the concept of Pawongan, emphasizes the importance of harmonious relationships with fellow human beings that are relevant to the context of relations, including romantic relations with the opposite sex, so how individuals should interact in these romantic relations is included in the value of benevolence. If Universalism refers to the welfare of the wider community and to nature, then benevolence is more focused on the scope of individuals that are more specific [11].

According to the participants, the right time for individuals be involved in a romantic relationship is determined by the stages of life as there is in the teachings of Hinduism, namely Catur Asrama, one of the teachings of Hindu religion. Catur Asrama contains four stages of human life, namely Bramacari Asrama, Grhasta Asrama, Wanaprasta Asrama, and Sannyasin (Bhiksuka) Asrama. Respondents emphasized the Brahmacari phase, the stage for individual to study or gain knowledge. Balinese adolescents in the Brahmacari period are expected to focus more on education, be able to control their desires, and avoid sexual behavior [15]. This has implications for the expectations of Balinese people about when an adolescent should be able to engage in a romantic relationship. Collins et.al. [2] examined a number of studies and found that social expectations, especially those related to norms of 
behavior based on age, contribute to the onset of dating behavior. Regan [16] also found that Asian adolescents tend to start romantic relationships at an older age and have less romantic experiences compared to adolescents from Western countries.

Furthermore, participants argue that adolescents should not get married at a young age to avoid negative consequences due to the lack of mental readiness of adolescents in fostering the household. They were also identifying behaviors that prohibited to be carried out based on religious norms such as premarital sexual intercourse and cohabiting. The values of conformity and security are implicated in these restrictions. The value of conformity is emphasized as an effort to shape adolescent behavior that is compliant with social expectations or norms that are part of the traditions of Balinese society itself. While the value of security becomes an important part related to the hope of achieving stability and harmonious relations in a wider scope.

Participants also identified Tat Twam Asi's philosophy as a value related to romantic relationships. This concept explains how individuals must treat others well the same way they want to be treated well by others [17]. The value of benevolence becomes dominant in this concept, where adolescents in their relationships will become reliable, trustworthy, and always trying to do good things to others. The concepts of empathy and sympathy are an important part of this philosophy, so that adolescents will consider every decision taken so as not to harm their partners and put their partners in the same position as they want to be treated.

One guide for adolescents' behaviors in Balinese culture emphasizes expectations about how behavior should be formed based on gender. Adolescents put forward the term Luh Luwih

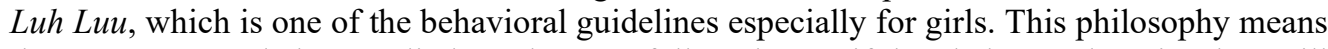
that women must behave politely and respectfully, whereas if they behave otherwise they will be judged poorly [18]. Women are obliged to look after themselves properly and not behave in a way that is detrimental and damaging, and men must respect women. This guide implies the value of conformity, because women are expected to obey behavioral standards and maintain their self-esteem. Moosman \& Roosa [19] in their research identified the existence of social role values and traditional gender roles that affect relations between the opposite sex. The value of traditional gender roles is determined by the belief that women are primarily responsible for raising and managing domestic work, and is more obedient, while men are responsible for making household decisions, being the sole provider, and being considered stronger.

Differences in gender roles in Balinese society can also be seen in the different roles and positions between men and women in society. Balinese traditions emphasize that men have position as the head of the family and demanded to be more responsible, while women have the responsibility in customary and religious activities. This position is important to consider in a romantic relationship because men and women need to be aware of and willing to accept their positions and responsibilities. Another consideration reported by adolescent related to the prohibition on incest and this became a very important consideration because they believed that this practice against the traditions and religion.

In terms of partner selection, Balinese adolescents were considering the importance of knowing the personality of a prospective romantic partner, specifically choosing a partner from the same caste and religion. The consideration of the level of caste and the similarity of religion in romantic partners' selection also shows the value of tradition, especially related to social hierarchy in Balinese society. Security value also arises in the context of this partner selection, related to the aims for avoiding conflicts in the family and the wider environment. Lalonde, et.al., [20] found that culture influences the preferences of "traditional" couples. Asian participants have higher self-construal interdependence and traditional family 
expectations as well as traditional partner preference preferences when compared to participants with European culture.

Philosophy and religious teachings that guide Balinese behavior specifically implemented in the form of romantic-related behavior, such as maintaining social ethics by being polite with the opposite sex and paying attention to the rules that exist in society. These responses contain values that are more universal even though they still show the characteristics of Eastern culture, especially in the context of romantic relations. The need to have sense of shame and protecting the family good name also considered important. This implemented the importance of conformity values, associated with efforts to limit behavior to meet the expectations of the social environment and avoid conflicts, and the value of security, which leads to the stability of life and relationships.

A number of attitudes and behaviors in a relationship that are considered important in maintaining romantic relationships, represented the value of benevolence and conformity, such as honesty, compassion, respect, loyalty, understanding, friendliness, responsibility, sincerity and sincerity, as well as not using and not imposing the will on a partner. In particular, for adolescents, the blessing from parents was also an important thing that must exist in a romantic relationship so that relationships avoid conflict and can lead to more serious relation. Dion \& Dion [21] explain that in individualistic cultures, adolescents value the freedom to find partners who satisfy their own personal development without the intervention of parents, and friends play an important socialization role in this process. Conversely, in the collective culture of parents can be the main power of socialization for teenage romance, and the transmission of cultural knowledge about romantic love can emphasize respect for the family of origin, the importance of responsibility, the function of having children.

The results of this exploration also provide a glimpse into the attitudes of adolescents regarding the consideration of values or philosophies that they identify in romantic relationships. After identified values that were relevant to romantic relationships, participants also revealed whether those values would be considered or not when they were in a romantic relationship. There is a group of adolescents who consider the values identified with some reasons, such as consideration of acceptance by the community and parents' environment, influence on learning motivation, avoiding conflict and regret, so as not to damage oneself and partner, as an effort to preserve culture and follow religious teachings. Some adolescents reported that they do not feel the need to consider those values and engaged in romantic relationships as they wish. This finding showed that a small number of Balinese adolescents, when associated with Schwartz's value theory, begin to refer to Openness to change values. This refers to the basic value of self-direction, in which there is independence in thinking and behaving, and independently determining his actions by growing his own thoughts, in this case about how adolescents perceive the romantic relationships they live.

While the findings discussed above have identified a number of basic values contained in the teachings of Hinduism and philosophy, as well as considerations of perceived attitudes and behaviors related to romantic relationships. Traditional values become an umbrella for other basic values, such as Universalism, conformity, security, and benevolence. The basic values of Universalism and Benevolence are part of Self-transcendence high order values; while the basic values Conformity, Tradition, and Security explain about Conservation high order values. Conservation is a set of values that emphasizes orderliness, self-control, maintaining what has existed in the past, and tends to be resistant to change. Self-transcendence emphasizes attention to the welfare and interest in others and the environment [11]. Both of 
these high order values show the cultural characteristics of Balinese people, and may also be a representation of the values that people of other Eastern cultures have.

At the cultural level, from the theory put forward by Schwartz [13] the findings of this study indicate that Balinese culture emphasizes embeddedness which views that individuals are collectively bound to other individuals. People have a shared way of life and gain meaning in life by maintaining their social relations and striving to achieve common goals. This culture respects tradition and wisdom, and limits behavior that risks disturbing order in the tradition. The Balinese culture, reflected in many of its philosophies of life, characterizes a culture that prioritizes harmonization in life, trying to understand and appreciate more than changing what it has. This leads to the goal of achieving peace in life in all aspects.

\section{Conclusions}

The results of the study above which tried to identify values that are considered relevant by Balinese parents and adolescents, if examined further through the basic dimensions in the value structure proposed by Schwartz then it appears that the value orientation in romantic relations in Balinese society refers to the value group Conservation, which includes Tradition, Conformity, and Security value types; and the Self-Transcendence value group, which includes Universalism and Benevolence value types. For the minority of adolescents who do not consider certain values when establishing a romantic relationship, the type of Openness to Change values seems to be dominating.

The interrelationships between basic types of values, such as Tradition, Conformity, Security, Benevolence, and Universalism, explain the priority of values in romantic relationships that reflect the characteristics of Balinese society. The problems occurs in the context of the romantic relationships of Balinese adolescents nowadays can be discussed from the concept of values possessed by Balinese adolescents themselves. If the findings in this study indicate that Balinese adolescents are able to identify the values they consider important and all refer to values that have a positive impact on life, then the next question is how the psychological dynamic of values transmission that occur in Balinese society is related to problematic behaviors on romantic relationships among adolescents.

\section{References}

[1] W. A. Collins, "More than myth: The developmental significance of romantic relationships during adolescence," J. Res. Adolesc., vol. 13, no. 1, pp. 1-24, 2003.

[2] W. A. Collins, D. P. Welsh, and W. Furman, "Adolescent romantic relationships," Annu. Rev. Psychol., vol. 60, pp. 631-652, 2009.

[3] S. E. Cavanagh, "The social construction of romantic relationships in adolescence: Examining the role of peer networks, gender, and race," Sociol. Inq., vol. 77, no. 4, pp. 572-600, 2007.

[4] R. W. Simon, D. Eder, and C. Evans, "The development of feeling norms underlying romantic love among adolescent females," Soc. Psychol. Q., pp. 29-46, 1992.

[5] E. Lesch and C. Furphy, "South African adolescents' constructions of intimacy in romantic relationships," J. Adolesc. Res., vol. 28, no. 6, pp. 619-641, 2013.

[6] A. Kuperberg and J. E. Padgett, "The role of culture in explaining college students' selection into hookups, dates, and long-term romantic relationships," J. Soc. Pers. Relat., vol. 33, no. 8, pp. 1070-1096, 2016.

[7] Z. H. Li, J. Connolly, D. Jiang, D. Pepler, and W. Craig, "Adolescent romantic relationships in China and Canada: A cross-national comparison," Int. J. Behav. Dev., vol. 34, no. 2, pp. 113 
120,2010

[8] P. H. Collins, Black feminist thought: Knowledge, consciousness, and the politics of empowerment. Routledge, 2002.

[9] S. H. Schwartz and J. Cieciuch, Values. Dalam D. Bartram, F. Cheung, K Geisinger, J. Hattie, D. Iliescu, \& F. Leong (Eds.), International Test Commision Handbook of Testing and Assessment (hlm. 106-119). New York: Oxford University Press, 2016.

[10] S. H. Schwartz, "Universals in the content and structure of values: Theoretical advances and empirical tests in 20 countries," Adv. Exp. Soc. Psychol., vol. 25, no. 1, pp. 1-65, 1992.

[11] S. H. Schwartz, "An overview of the Schwartz theory of basic values," Online readings Psychol. Cult., vol. 2, no. 1, pp. 919-2307, 2012.

[12] S. H. Schwartz, "Are there universal aspects in the structure and contents of human values?," $J$. Soc. Issues, vol. 50, no. 4, pp. 19-45, 1994.

[13] S. H. Schwartz, "Cultural value orientations: Nature and implications of national differences," Moscow Publ. house SU HSE, 2008.

[14] I. W. Sukarma, "Tri Hita Karana theoretical basic of moral Hindu," Int. J. Linguist. Lit. Cult., vol. 2, no. 3, pp. 102-116, 2016.

[15] D. A. R. Wulandari and I. N. Juliawan, "Peningkatan Mutu Pembelajaran Agama Hindu Dalam Mewujudkan Perubahan Mental Siswa," J. Penjaminan Mutu, vol. 4, no. 1, pp. 7-19, 2018.

[16] P. C. Regan, R. Durvasula, L. Howell, O. Ureno, and M. Rea, "Gender, ethnicity, and the developmental timing of first sexual and romantic experiences," Soc. Behav. Personal. an Int. J., vol. 32, no. 7, pp. 667-676, 2004.

[17] M. K. Adhi, "TAT TWAM ASI: ADAPTASI NILAI KEARIFAN LOKAL DALAM PENGENTASAN KEMISKINAN KULTURAL," in Seminar Nasional Riset Inovatif, 2016, vol. 4.

[18] N. L. A. Satriani, "Respon dan Koping Perempuan Bali yang Mengalami Kekerasan dalam Rumah Tangga dan faktor Sosial Budaya Bali yang Mempengaruhinya di Kecamatan Bebandem Kabupaten Karangasem, Bali: Studi Grounded Theory," Universitas Indonesia, 2010

[19] D. A. V Moosmann and M. W. Roosa, "Exploring Mexican American adolescent romantic relationship profiles and adjustment," J. Adolesc., vol. 43, pp. 181-192, 2015.

[20] R. N. Lalonde, M. Hynie, M. Pannu, and S. Tatla, "The role of culture in interpersonal relationships: Do second generation South Asian Canadians want a traditional partner?," $J$. Cross. Cult. Psychol., vol. 35, no. 5, pp. 503-524, 2004.

[21] I. Seiffge-Krenke et al., "All they need is love? Placing romantic stress in the context of other stressors: A 17-nation study," Int. J. Behav. Dev., vol. 34, no. 2, pp. 106-112, 2010. 